\title{
Relationship between biochemical analytes and milk fat/protein in Holstein cows
}

\author{
Omar R. Prado ${ }^{a}$, Jesús B. Morales ${ }^{\mathrm{b}}$, Jaime O. Molinaa, ${ }^{\mathrm{a}, \mathrm{c}}$ Luis M. García ${ }^{\mathrm{c}}$, \\ Rafael B. Macedo ${ }^{a}$, Juan R. Hernández ${ }^{a}$, Arturo C. García ${ }^{*}$
}

\begin{abstract}
The aim of this study was to assess the relationship between biochemical analytes and milk fat/protein in high-yield (DIM: $42 \pm 10 \mathrm{~d}$ postpartum) and low-yield (DIM: $91 \pm 11 \mathrm{~d}$ postpartum) Holstein cows. Stepwise regression analysis was used to evaluate the relationships of biochemical analytes with the fat and protein content of the milk from 126 Holstein cows belonging to nine intensive housed dairy farms. The comparison between the two groups showed differences $(P<0.05)$ in the milk yield, milk fat and milk fat/protein ratio, with the higher values in high-yield cows. The correlations between milk fat, milk protein, milk fat/protein ratio and biochemical analytes concentrations, were assessed within each group. Milk fat level was positively correlated to cholesterol, triglycerides, $\beta$-hydroxybutyrate and albumin in high-yield cows. Milk protein level was positively correlated to urea, and negatively correlated to sodium ion, potassium ion and chlorine ion in high-yield cows. A virtually linear dependence has also been found between milk fat and triglycerides, between milk protein and urea, and between milk fat/protein ratio and cholesterol, and triglycerides in low-yield cows. The metabolic profiles provide a practical tool, to present an insight into the underlying physiological mechanisms of lactation, and the identification of relationships between key analytes and components of milk, such as protein and fat content.

Key words: dairy cow, blood chemistry, milk fat, milk protein.
\end{abstract}

\section{INTRODUCTION}

Current advances and trends in milk consumption and dairy industry, incentivise producers to maximize the fat and protein content of milk, above the $\mathrm{L}$ or $\mathrm{kg}$ of milk production (Manterola 2011). In the specific case of Mexico, the dairy industry sets a price for standard milk, with composition and quality defined, and the fat and protein content of milk receives economic incentives (Licons ${ }^{\mathrm{a}}$ 2013). These provisions in the dairy market, have attracted considerable scientific interest in technologies that allow to modify the chemical concentration and composition of fat and milk protein. In this regard, it is worth noting that the mammary epithelial cells utilize as much as $80 \%$ of available nutrients in blood for the synthesis of milk components (McManaman and Neville 2003).

The Compton metabolic profile test was designed by Payne to indicate whether a herd is liable to production disease (Payne 1972, Payne et al 1973). The focus of this methodology has since been adapted and modified, helping to clarify many topics related to reproductive disorder and periparturient disease in dairy cows (van Saun 2010, García et al 2015 ). Other authors (Bjerre-Harpoth et al 2012) have used multiple regression analysis to study the relationships between biochemical analytes and feeding,

Accepted: 02.10.2018

aFacultad de Medicina Veterinaria y Zootecnia, Universidad de Colima, Tecomán, México.

bDepartamento de Producción Agrícola y Animal, Universidad Autónoma Metropolitana, México.

${ }^{\mathrm{c} C o o r d i n a c i o ́ n ~ G e n e r a l ~ d e ~ I n v e s t i g a c i o ́ n ~ C i e n t i ́ f i c a, ~ C e n t r o ~ U n i v e r s i t a r i o ~}$ de Investigación y Desarrollo Agropecuario, Universidad de Colima, Tecomán, México.

*Corresponding author: A García Casillas, cesargarciacasillas@ hotmail.com and reported that good serum predictors of ration nutrient variables were cholesterol (COL), inorganic phosphate $\left(\mathrm{PO}_{4}^{-3}\right)$, triglycerides (TAG) and globulin (GLOB).

Nowadays three metabolic profiles are assessed: energy, protein, and mineral. The main biochemical analytes used to assess the energy profile are: glucose (GLU), not absorbed in large amounts from the digestive system of dairy cows but synthesised in significant amounts by the liver from volatile fatty acids (VFA) particularly propionic acid (Šamanc et al 2011); COL, in cows is captured by high-density lipoproteins (HDLc) instead of low-density lipoproteins (LDLc) as in the case of humans, rabbits, pigs, and some species of monkeys whose pattern is LDLc (Civeira et al 2013). Therefore, during the early lactation, any increase in COL is paralleled by an increase in HDLc (Kaneko et al 2008); TAG, lipids that circulate in the blood, used by cells to produce adenosine triphosphate (ATP) (Kaneko et al 2008); $\beta$-hydroxybutyrate ( $\beta$-HBA), which is the most important and abundant ketone body in dairy cows (Duffield et al 2009); and non-esterified fatty acids (NEFA), which are related to both lipomobilisation and the degree of negative energy balance (NEB) (Ospina et al 2010). The essential biochemical analytes for assessing the protein profile are: blood urea nitrogen (BUN), useful for measuring the adequacy of dietary protein levels as well as nitrogen utilisation efficiency in which rumen degradable protein (RDP) and rumen undegradable protein (RUP) are coordinated with starch degradabilities to optimise rumen microbial protein synthesis (Prodanović et al 2012); albumin (ALB), that can reflect hepatic insufficiency by decreasing its concentration (Whitaker 2000); GLOB, that is increased in response to an inflammatory process (Kaneko et al 2008); and total protein (PROT-T), which gives information about amino acids and tissue protein balance (Stojević et al 2005). 
Considering the use of body tissues in response to NEB, the produced ketone bodies (by its acidic nature) decrease the natural buffering capacity of bicarbonate $\left(\mathrm{HCO}_{3}{ }^{-}\right)$, increasing the anion gap in the blood, and causing changes in $\mathrm{pH}$ by movements of electrolytes, water, and carbon dioxide $\left(\mathrm{CO}_{2}\right)$ (Herdt et al 2000, García et al 2017). The essential biochemical analytes of the mineral profile are: sodium ion $\left(\mathrm{Na}^{+}\right)$, which is the main extracellular fluid cation and an important determinant of body water homeostasis (Kume et al 2011); chlorine ion $\left(\mathrm{Cl}^{-}\right)$, the most abundant anion in extracellular fluid (Soetan et al 2010); potassium ion $\left(\mathrm{K}^{+}\right)$, the principal intracellular cation in mammals (van Saun 2006); calcium ion $\left(\mathrm{Ca}^{2+}\right)$ and magnesium ion $\left(\mathrm{Mg}^{2+}\right)$ due to their importance in the rapidity of metabolic reactions and their role in the transmembrane transport systems (Houillier 2014); $\mathrm{PO}_{4}^{-3}$, its insufficient intake may result in a reduction in lactation performance and has been purported to lead to inadequate reproductive performance (Brscic et al 2015); and the enzyme $\gamma$-glutamyl transpeptidase $(\gamma-\mathrm{GT})$, an essential indicator of hepatic lesions and function (Stojević et al 2005). Periods of inadequate water intake and stress will impact levels of $\mathrm{Na}^{+}, \mathrm{Cl}^{-}$and $\mathrm{K}^{+}$, and subsequently the physiological roles they serve (Kume et al 2011). $\mathrm{PO}_{4}^{-3}$ deficiency is most likely to occur in animals consuming poor quality forages from soils deficient in $\mathrm{PO}_{4}^{-3}$ as well as excessively mature forages and crop residues that contain less than $0.25 \%$ of $\mathrm{PO}_{4}^{-3}$ content on a dry matter basis (NRC 2001).

Also, the effect of metabolic diseases on milk composition suggests that there is a close relationship between biochemical analytes and milk constituents, reduction in milk proteins during metabolic alkalosis (Filipejová et al 2011), reduction in milk fat during rumen acidosis (Kraut and Madias 2010), and reduction in lactose in all metabolic disorders (García et al 2015ª). For this reason, the present study compared the metabolic conditions of high-yield cows (during early lactation) and low-yield cows (during mid lactation) and the relationship with fat and protein content of milk in Holstein cows.

\section{MATERIAL AND METHODS}

All animals in this study were kept following the guidelines of the Institutional Animal Care and Use Committee of the University of Colima. The study was carried out by sampling and analysing blood serums and milk obtained from 126 Holstein cows belonging to nine intensive housed dairy farms. All farms were located in the Mexican temperate zone, at an altitude of 2,260 m above sea level, with sub-humid climate (Köppen $\mathrm{Cfb}$ ) (Peel et al 2007). The average temperature is $15^{\circ} \mathrm{C}$, and pluvial precipitation is $620 \mathrm{~mm} /$ year. Cows were selected considering that in multiparous cows, the period of peak milk production in early lactation is usually between 30 to 60 d after calving (Oetzel 2004, Quiroz-Rocha et al 2009); and the peak milk production generally begins to descend until 12 to 14 wk postpartum (NRC 2001). Seven high-yield cows [Days in milk (DIM): $42 \pm 10 \mathrm{~d}$ postpartum; range: 26-58 d postpartum; Milk Production (Mean \pm SD): 34.96 $\pm 1.69 \mathrm{~L} / \mathrm{d}$ ], and seven low-yield cows [DIM: $91 \pm 11 \mathrm{~d}$ postpartum; range: 73-109 d postpartum; Milk Production (Mean \pm SD): $16.14 \pm 1.12 \mathrm{~L} / \mathrm{d}]$ were selected from each farm. All animals were $2^{\text {nd }}$ or $3^{\text {rd }}$ calving healthy Holstein cows. Milk producing cows were milked twice daily. The feeding of the high-yield cows diet included: $7.14 \mathrm{~kg}$ alfalfa hay, $1.32 \mathrm{~kg}$ of alfalfa silage, $1 \mathrm{~kg}$ of oat straw, $14.06 \mathrm{~kg}$ of corn silage, and $3.38 \mathrm{~kg}$ of triticale silage; low-yield cows diet included: $4 \mathrm{~kg}$ alfalfa hay, $14.3 \mathrm{~kg}$ of chopped alfalfa, $1.5 \mathrm{~kg}$ of oat straw, and $2.5 \mathrm{~kg}$ of cracked or steam-flaked corn. Additionally, both groups received $0.3 \mathrm{~kg}$ of $\mathrm{HCO}_{3}^{-}$, mineral supplements $\left(\mathrm{Ca}^{2+} 22.6 \%, \mathrm{PO}_{4}^{-3} 11.9 \%, \mathrm{Mg}^{2+} 5.6 \%\right.$ on average), and free access to fresh water. Concentrate (18\% PC) was supplied at a rate of $13.25 \mathrm{~kg} / \mathrm{d}$ for highyield cows, and $7 \mathrm{~kg} / \mathrm{d}$ for low-yield cows.

\section{MILK COLLECTION AND DETERMINATION OF FAT AND PROTEIN CONTENT}

Milk samples (100 mL each) were collected during morning milking. All samples were stored at $4{ }^{\circ} \mathrm{C}$ with a preservative (Bronopol $0.04 \mathrm{~g} / 100 \mathrm{~mL}$; Broad Spectrum Microtabs II; D\&F Control Systems, Inc., Dublin, CA), and transported in a portable cooler (Thermoelectric Cooler Car/Home M5644-710; Coleman Company, Kansas, United States) to the dairy laboratory of the Universidad Autónoma Metropolitana campus Xochimilco, where they were analysed for fat and protein by Fourier transform infrared spectroscopy (MilkoScan 133B; Foss Electric., Hillerod, Denmark).

\section{BLOOD COLLECTION AND DETERMINATION OF BIOCHEMICAL ANALYTES}

Blood samples were collected, after the first morning milking and before feeding, by puncture of the coccygeal vein using $8.5 \mathrm{~mL}$ vacuum tubes with clot activator and serum separator gel (BD Vacutainer 367988; BectonDickinson Co., Franklin Lakes, United States). Just after blood collection, to avoid a drop in GLU, the serum was separated by centrifuging directly at the farms at 1,500 x $g$ for 10 min as described by van Saun (2010) using a portable centrifuge (Porta-Spin C828; UNICO., Dayton, United States). Subsequently, the serum samples were separated using $1.5 \mathrm{~mL}$ tubes with lid (Tubes Safe-Lock 3810X; Eppendorf, Madrid, Spain) and transported at $4{ }^{\circ} \mathrm{C}$ in a portable cooler (Thermoelectric Cooler Car/Home M5644-710; Coleman Company, Kansas, United States) to the clinical laboratory of the Universidad Autónoma Metropolitana campus Xochimilco, where they were frozen at $-20{ }^{\circ} \mathrm{C}$ until analysis. The concentration of each biochemical analyte was determined with an UV/Vis spectrophotometer (Biochemistry Analyzer ES-218; KONTROLab., Guidonia, 
Italy). Table 1 describes measured biochemical analytes, the analytical method employed to obtain each parameter, and the corresponding commercial reagents used.

The precision and reliability of the techniques was controlled using lyophilized bovine control serum (SPINTROL NORMAL 1002100; Spinreact, Girona, Spain) and Assayed Bovine Multi-Sera (AL 1027; Randox Laboratories., Northern Ireland, United Kingdom). Hemolysis of serum was recorded on a qualitative scale of 0 (none) to 3 (dark) (Quiroz-Rocha et al 2009). Samples showing hemolysis scores of 2 and above constituted less than $2 \%$ of all samples, and did not introduce a significant bias in any of the tested models after statistical analysis; thus, the influence of serum hemolysis was ignored.

\section{STATISTICAL ANALYSIS}

The comparison between groups (high-yield cows vs. low-yield cows) was assessed using Analysis of Variance. A multiple comparison test of Tukey was performed when the effect of group was found to be significant $(P<0.05)$. Stepwise regression analysis (PROC REG, SAS, System, v. 8.2, Cary, NC) was used to evaluate the relationships of different blood analytes to fat and protein content of milk. The following regression models were tested:

$$
\begin{gathered}
Y=\beta_{0}+\beta_{1} \cdot X_{1 i}+e_{1} \\
Y=\beta_{0}+\beta_{1} \cdot X_{1 i}+\beta_{2} \cdot X_{2 i}+\ldots+\beta_{k} \cdot X_{\mathrm{ki}}+e_{1}
\end{gathered}
$$

where:

$Y=$ milk fat, milk protein, and milk fat/protein ratio;

$\beta_{0}=$ intercept;

$\beta_{1}=$ slope (coefficient of estimate);

$X_{1 i}=\mathrm{GLU}, \mathrm{COL}$, TAG, $\beta$-HBA, NEFA, BUN, ALB, GLOB, PROT-T, $\mathrm{Ca}^{2+}, \mathrm{PO}_{4}^{-3}, \mathrm{Na}^{+}, \mathrm{K}^{+}, \mathrm{Mg}^{2+}, \mathrm{Cl}^{-}, \mathrm{CO}_{2}, \mathrm{HCO}_{3}^{-}$, anion gap, and $\gamma-\mathrm{GT}$ respectively; and

$e_{1}=$ standard error of estimate.

The goodness-of-fit of each model was estimated by Pearson correlation coefficients and R square $\left(\mathrm{R}^{2}\right)$. A diagnosis for outlier values was performed using robust multivariate outlier detection (OUTLIER; SAS, 2001). This macro calculates the robust Mahalanobis distance for each observation ${ }^{1}$. The following model was tested:

$$
d_{m}(\mathrm{x}, \overline{\mathrm{x}})=\sqrt{(\mathrm{x}-\overline{\mathrm{x}}) \sum_{x}^{-1}(\mathrm{x}-\overline{\mathrm{x}})}
$$

where:

$d m(\mathrm{x}, \overline{\mathrm{x}})=$ robust Mahalanobis distance;

$\mathrm{x}=$ vector of the observation;

$\overline{\mathrm{x}}=$ vector average of the observations; and

$\sum_{x}^{-1}=$ variance-covariance matrix of the observations.

1 http://www.datavis.ca/sasmac/outlier.html Research date: January 07, 2017.
A diagnosis for regressions' main asssumptions was performed (PROC UNIVARIATE; SAS, 2001). Linear functional form was visually checked by a normal plot. Shapiro-Wilk test was used to check normality of residuals. Homoscedasticity was checked by plotting residual versus predicted values, and the Durbin-Watson test was employed to check for error uncorrelation.

\section{RESULTS}

The reference value and descriptive statistics for milk yield/composition, GLU, COL, TAG, $\beta$-HBA, NEFA, BUN, ALB, GLOB, PROT-T, $\mathrm{Ca}^{2+}, \mathrm{PO}_{4}^{-3}, \mathrm{Na}^{+}, \mathrm{K}^{+}, \mathrm{Mg}^{2+}, \mathrm{Cl}^{-}$, $\mathrm{CO}_{2}, \mathrm{HCO}_{3}^{-}$, anion gap, and $\gamma-\mathrm{GT}$, determined from 126 metabolic profiles (63 Holstein cows/group) are shown in table 2. Pearson correlation coefficients between biochemical analytes and milk fat/protein in high-yield cows and low-yield cows, are shown in table 3. Differences $(P<0.05)$ between the two groups were found for milk yield, milk fat and milk fat/protein ratio, with the higher values corresponding to high-yield cows (table 2). Milk fat level was positively correlated to COL, TAG, $\beta$-HBA and ALB in high-yield cows. Milk protein level was positively correlated to BUN, and negatively correlated to $\mathrm{Na}^{+}, \mathrm{K}^{+}$, and $\mathrm{Cl}^{-}$in high-yield cows. A virtually linear dependence has also been found between milk fat and TAG, between milk protein and BUN, and between milk fat/protein ratio and COL and TAG in low-yield cows (table 3).

\section{DISCUSSION}

Increased milk yield due to genetic selection in dairy herds has enhanced the gap between energy expenditure and energy availability, especially during early lactation (table 2) (Ospina et al 2010). Dairy cows have to fulfill this difference by an increased use of their body reserves (Bjerre-Harpoth et al 2012). This mechanism involves an incomplete oxidation of TAG, which originates subclinical ketosis (SCK) in cows by the biosynthesis of ketone bodies acetoacetate (AcAc) and $\beta$-HBA produced in the liver by mitochondrial $\beta$-oxidation (Quiroz-Rocha et al 2009). Synergistically to the process of lipid biohydrogenation in the rumen, the carbohydrates supplied in the diet are fermented by bacterial action producing VFA (Kim et al 2009). The fatty acids of $\mathrm{C} 4$ to $\mathrm{C} 10$ of the lipid fraction of milk are synthesised de novo in the mammary gland (Harvatine et al 2009). The VFA acetate and butyrate, serve as precursors, and the groups of two carbons added during the elongation, come from AcAc and $\beta$-HBA (Houten and Wanders 2010). This means that the positive correlation between milk fat and $\beta$-HBA $(r=0.64 ; P<0.01)$ in highyield cows (figure 1), outlines the function of this analyte in the synthesis of milk fat (Ospina et al 2010), clarifying the importance of $\beta$-HBA in the increase of the fat content of milk, mainly in the synthesis of saturated fatty acids (García et al 2015 ${ }^{\mathrm{b}}$ ). 
Table 1. Biochemical analytes, analytical methods, and corresponding commercial reagents.

\begin{tabular}{|c|c|c|c|}
\hline Analyte & Unit & Method & Reagent \\
\hline \multicolumn{4}{|l|}{ Energy profile } \\
\hline Glucose (GLU) & $\mathrm{mM}$ & Colorimetric. Trinder ${ }^{\mathrm{a}}$ & $1001190^{1}$ \\
\hline Cholesterol (COL) & $\mathrm{mM}$ & Colorimetric. Liquid ${ }^{\mathrm{b}}$ & $41020^{1}$ \\
\hline Triglycerides (TAG) & $\mathrm{mM}$ & Colorimetric. Liquid ${ }^{c}$ & $41032^{1}$ \\
\hline$\beta$-hydroxybutyrate ( $\beta$-HBA) & $\mathrm{mM}$ & Enzymatic $^{\mathrm{d}}$ & RB $1007^{2}$ \\
\hline Non-esterified fatty acids (NEFA) & $\mathrm{mM}$ & Enzymatic $^{\mathrm{e}}$ & FA $115^{2}$ \\
\hline \multicolumn{4}{|l|}{ Protein profile } \\
\hline Urea (BUN) & $\mathrm{mM}$ & Enzymatic $^{f}$ & $1001333^{1}$ \\
\hline Albumin (ALB) & $\mathrm{g} / \mathrm{dL}$ & Colorimetric. Bromocresol green & $1001020^{1}$ \\
\hline Globulin (GLOB) & $\mathrm{g} / \mathrm{dL}$ & $(\mathrm{PROT}-\mathrm{T})-(\mathrm{ALB})$ & Difference \\
\hline Total protein (PROT-T) & $\mathrm{g} / \mathrm{dL}$ & Colorimetric. Biuret & $1001291^{1}$ \\
\hline \multicolumn{4}{|l|}{ Mineral profile } \\
\hline Calcium ion $\left(\mathrm{Ca}^{2+}\right)$ & $\mathrm{mM}$ & Colorimetric. Arsenazo III & CA $2391^{2}$ \\
\hline Inorganic phosphate $\left(\mathrm{PO}_{4}^{-3}\right)$ & $\mathrm{mM}$ & Colorimetric. Phosphomolybdate & $1001155^{1}$ \\
\hline Sodium ion $\left(\mathrm{Na}^{+}\right)$ & $\mathrm{mM}$ & Enzymatic. Galactosidase & $1001385^{1}$ \\
\hline Potassium ion $\left(\mathrm{K}^{+}\right)$ & $\mathrm{mM}$ & Enzymatic & $1001395^{1}$ \\
\hline Magnesium ion $\left(\mathrm{Mg}^{2+}\right)$ & $\mathrm{mM}$ & Colorimetric. Xylidyl Blue & $1001286^{1}$ \\
\hline Chlorine ion $\left(\mathrm{Cl}^{-}\right)$ & $\mathrm{mM}$ & Colorimetric. Mercuric Thiocyanate & $1001360^{1}$ \\
\hline Carbon dioxide $\left(\mathrm{CO}_{2}\right)$ & $\mathrm{mM}$ & Enzymatic $^{\text {h }}$ & $\mathrm{CD} 127^{2}$ \\
\hline Bicarbonate $\left(\mathrm{HCO}_{3}^{-}\right)$ & $\mathrm{mM}$ & Enzymatic by $\mathrm{CO}_{2}$ total and gas dissolved & $99852^{3}$ \\
\hline Anion gap & $\mathrm{mM}$ & {$\left[\left(\mathrm{Na}^{+}+\mathrm{K}^{+}\right)-\left(\mathrm{Cl}^{-}+\mathrm{HCO}_{3}^{-}\right)\right]$} & Difference \\
\hline \multicolumn{4}{|l|}{ Hepatic enzyme } \\
\hline$\gamma$-glutamyl transpeptidase $(\gamma$-GT) & $\mathrm{U} / \mathrm{L}$ & Enzymatic. Carboxy substrate & $41292^{1}$ \\
\hline
\end{tabular}

${ }^{\mathrm{a}}$ Glucose Oxidase-Peroxidase; ${ }^{\mathrm{b}}$ Cholesterol Oxidase-Peroxidase; ${ }^{\mathrm{c}}$ Glycerol Phosphate Dehydrogenase-Peroxidase; ${ }^{\mathrm{d}} \beta$-hydroxybutyrate Dehydroge-

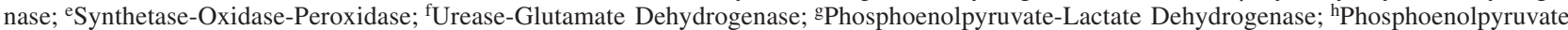
Carboxylase- Malate Dehydrogenase; ${ }^{1}$ Spinreact., Girona, Spain; ${ }^{2}$ Randox Laboratories., Northern Ireland, United Kingdom; ${ }^{3}$ Biolabo Laboratory, Grandcamp-Maisy, France.

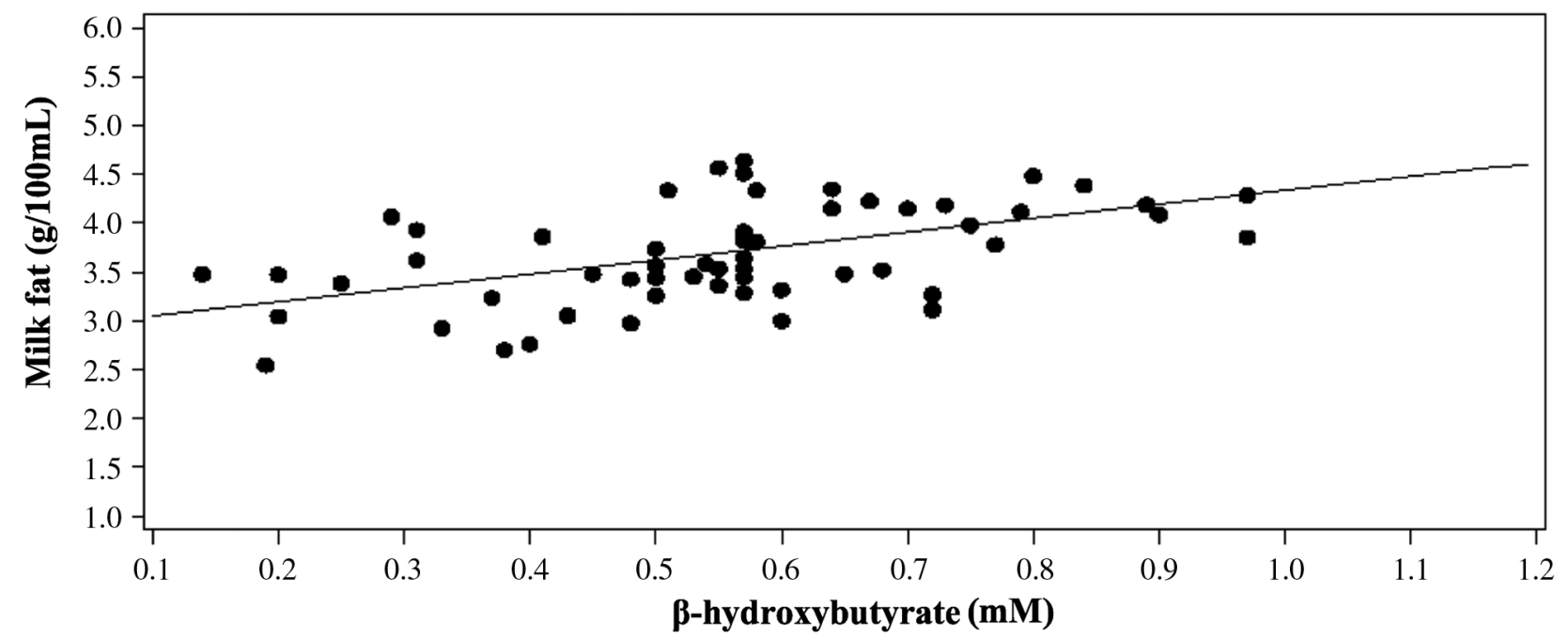

Figure 1. Relationship between milk fat and $\beta$-hydroxybutyrate ( $\mathrm{n}=63$ high-yield cows). Milk fat $(\bullet)$; predicted response (一). 
Table 2. Reference value, mean (x), standard deviation (SD), for milk yield/composition and different biochemical analytes in intensive housed dairy farms ( $n=63$ Holstein cows/group).

\begin{tabular}{|c|c|c|c|}
\hline Item & Reference $^{1}$ & High-yield cows ${ }^{2}$ & Low-yield cows ${ }^{3}$ \\
\hline Milk yield (L/d)* & & $34.96 \pm 1.69^{\mathrm{a}}$ & $16.14 \pm 1.12^{b}$ \\
\hline Days in milk (DIM) & & $42 \pm 10$ & $91 \pm 11$ \\
\hline Milk fat $(\mathrm{g} / 100 \mathrm{~mL}) *$ & & $3.71 \pm 0.51^{\mathrm{a}}$ & $3.37 \pm 0.56^{\mathrm{b}}$ \\
\hline Milk protein $(\mathrm{g} / 100 \mathrm{~mL})$ & & $2.91 \pm 0.22$ & $2.88 \pm 0.21$ \\
\hline Milk fat/protein ratio* & & $1.27 \pm 0.15^{\mathrm{a}}$ & $1.16 \pm 0.16^{\mathrm{b}}$ \\
\hline \multicolumn{4}{|l|}{ Energy profile } \\
\hline Glucose (mM) & $3.19 \pm 0.38$ & $3.01 \pm 0.65$ & $3.18 \pm 0.69$ \\
\hline Cholesterol $(\mathrm{mM})^{*}$ & $2.59 \pm 0.51$ & $5.70 \pm 1.73^{\mathrm{a}}$ & $5.05 \pm 1.73^{\mathrm{b}}$ \\
\hline Triglycerides (mM) & $0.10 \pm 0.10$ & $0.12 \pm 0.04$ & $0.12 \pm 0.05$ \\
\hline$\beta$-hydroxybutyrate $(\mathrm{mM})^{*}$ & $0.41 \pm 0.03$ & $0.56 \pm 0.20^{\mathrm{a}}$ & $0.48 \pm 0.21^{\mathrm{b}}$ \\
\hline Non-esterified fatty acids (mM) & $0.40 \pm 0.20$ & $0.10 \pm 0.05$ & $0.10 \pm 0.04$ \\
\hline \multicolumn{4}{|l|}{ Protein profile } \\
\hline Urea $(\mathrm{mM})$ & $8.90 \pm 1.80$ & $5.75 \pm 2.13$ & $5.75 \pm 2.01$ \\
\hline Albumin (g/dL) & $3.29 \pm 0.13$ & $3.52 \pm 0.66$ & $3.32 \pm 0.67$ \\
\hline Globulin (g/dL) & $3.24 \pm 0.24$ & $3.62 \pm 1.06$ & $3.65 \pm 1.32$ \\
\hline Total protein (g/dL) & $7.10 \pm 0.18$ & $7.14 \pm 1.43$ & $6.98 \pm 1.46$ \\
\hline \multicolumn{4}{|l|}{ Mineral profile } \\
\hline Calcium ion $(\mathrm{mM})^{*}$ & $2.78 \pm 0.15$ & $2.26 \pm 0.50^{\mathrm{a}}$ & $2.10 \pm 0.47^{\mathrm{b}}$ \\
\hline Inorganic phosphate (mM) & $1.95 \pm 0.15$ & $1.83 \pm 0.52$ & $1.78 \pm 0.43$ \\
\hline Sodium ion (mM) & $142 \pm 10$ & $122.98 \pm 12.61$ & $120.90 \pm 12.70$ \\
\hline Potassium ion (mM) & $4.8 \pm 1.0$ & $4.90 \pm 1.58$ & $4.93 \pm 1.81$ \\
\hline Magnesium ion (mM) & $0.84 \pm 0.10$ & $0.99 \pm 0.46$ & $0.97 \pm 0.51$ \\
\hline Chlorine ion (mM) & $104 \pm 7$ & $94.90 \pm 10.84$ & $95.37 \pm 11.15$ \\
\hline Carbon dioxide (mM) & $26.50 \pm 5.70$ & $26.44 \pm 3.07$ & $26.56 \pm 3.60$ \\
\hline Bicarbonate (mM) & $23 \pm 6$ & $23.80 \pm 2.76$ & $23.90 \pm 3.24$ \\
\hline Anion gap (mM) & $19.8 \pm 3$ & $9.19 \pm 13.14$ & $6.56 \pm 14.96$ \\
\hline \multicolumn{4}{|l|}{ Hepatic enzyme } \\
\hline$\gamma$-glutamyl transpeptidase (U/L) & $15.70 \pm 4.0$ & $31.87 \pm 10.58$ & $30.54 \pm 9.38$ \\
\hline
\end{tabular}

${ }^{1}$ (Kaneko et al 2008); ${ }^{2}$ range: $26-58 \mathrm{~d}$ postpartum; ${ }^{3}$ range: $73-109 \mathrm{~d}$ postpartum; * significant differences were obtained between groups indicated with different letters; $* P<0.05$.

The fatty acids of $\mathrm{C} 12$ to $\mathrm{C} 16$ are synthesised both $d e$ novo in the bovine mammary gland, and transported in the blood through a non-covalent binding with ALB (Bauman et al 2006). In the bovine mammary gland, the successive elongation of malonyl-Coenzyme A with acetyl-Coenzyme A to lengthen the fatty acid form to chains of more than C16 is not possible, because the necessary fatty acids elongase enzymes do not exist (Harvatine et al 2009).

Therefore, long-chain fatty acids used for the synthesis of milk fat have two main origins: i) TAG of food origin, transported in chylomicrons produced at the intestinal level and ii) COL esterified and free, transported in HDLc (Nafikov and Beitz 2007). This information shows similarity with the behaviour of TAG and COL in high-yield cows where a positive correlation was quantified, with a high coefficient $(\mathrm{r}=0.72 ; P<0.01)$ and $(\mathrm{r}=0.69 ; P<0.01)$ when they related to milk fat, respectively. The results suggest that TAG and COL are subordinate variables of milk fat, since the lipid concentration increases progressively as the TAG and COL increase (figure 2 and figure 3 ).

The lactocytes use the esterified COL to a fatty acid, to integrate along with carotenoids and fat-soluble vitamins, the nucleus of the fat globule, and the non-esterified $\mathrm{COL}$ to be part of the fat globule membrane, increasing the lipid fraction of the milk (Folnozic et al 2015, García et al $\left.2015^{\mathrm{b}}\right)$.

The ALB has the ability to bind a variety of hydrophobic substances as long-chain fatty acids and TAG, and transport them through the blood (Le Maux et al 2014). This means that the positive correlation between milk fat and ALB $(\mathrm{r}=0.60 ; P<0.01)$ in high-yield cows, reflects the amount of fatty acids bound to ALB, the equilibrium between the ALB that carries the fatty acids from lipolysis and the ALB that has delivered them to the bovine 
Table 3. Pearson correlation coefficients between biochemical analytes and milk fat/protein in high-yield cows and low-yield cows $(\mathrm{n}=63$ Holstein cows/group).

\begin{tabular}{|c|c|c|c|c|c|c|}
\hline & \multicolumn{3}{|c|}{ High-yield cows ${ }^{1}$} & \multicolumn{3}{|c|}{ Low-yield cows ${ }^{2}$} \\
\hline & Milk fat & Milk protein & $\begin{array}{l}\text { Milk fat/pro- } \\
\text { tein ratio }\end{array}$ & Milk fat & Milk protein & $\begin{array}{l}\text { Milk fat/ } \\
\text { protein ratio }\end{array}$ \\
\hline \multicolumn{7}{|l|}{ Energy profile } \\
\hline Glucose & 0.26 & 0.50 & 0.10 & 0.14 & 0.30 & 0.10 \\
\hline Cholesterol & $0.69 * *$ & 0.41 & 0.40 & 0.45 & 0.36 & $0.53 *$ \\
\hline Triglycerides & $0.72 * *$ & 0.44 & 0.45 & $0.67 * *$ & 0.43 & $0.64 * *$ \\
\hline$\beta$-hydroxybutyrate & $0.64 * *$ & 0.42 & 0.37 & 0.43 & 0.33 & 0.17 \\
\hline Non-esterified fatty acids & 0.10 & 0.20 & 0.14 & 0.22 & 0.10 & 0.30 \\
\hline \multicolumn{7}{|l|}{ Protein profile } \\
\hline Urea & 0.17 & $0.84 * * *$ & 0.10 & 0.20 & $0.54 *$ & 0.10 \\
\hline Albumin & $0.60 *$ & 0.45 & 0.20 & 0.46 & 0.36 & 0.10 \\
\hline Globulin & 0.20 & 0.43 & 0.10 & 0.26 & 0.40 & 0.17 \\
\hline Total protein & 0.17 & 0.10 & 0.14 & 0.22 & 0.10 & 0.10 \\
\hline \multicolumn{7}{|l|}{ Mineral profile } \\
\hline Calcium ion & 0.37 & 0.14 & 0.34 & 0.26 & 0.37 & 0.10 \\
\hline Inorganic phosphate & 0.24 & 0.22 & 0.10 & 0.10 & 0.40 & 0.14 \\
\hline Sodium ion & 0.24 & $-0.57 *$ & 0.10 & 0.24 & 0.42 & 0.10 \\
\hline Potassium ion & 0.33 & $-0.59 *$ & 0.24 & 0.30 & 0.10 & 0.36 \\
\hline Magnesium ion & 0.10 & 0.10 & 0.10 & 0.14 & 0.17 & 0.10 \\
\hline Chlorine ion & 0.30 & $-0.60 *$ & 0.10 & 0.10 & 0.37 & 0.26 \\
\hline Carbon dioxide & 0.22 & 0.43 & 0.10 & 0.10 & 0.17 & 0.10 \\
\hline Bicarbonate & 0.22 & 0.31 & 0.10 & 0.22 & 0.17 & 0.10 \\
\hline Anion gap & 0.10 & 0.17 & 0.10 & 0.31 & 0.10 & 0.34 \\
\hline \multicolumn{7}{|l|}{ Hepatic enzyme } \\
\hline$\gamma$-glutamyl transpeptidase & 0.10 & 0.10 & 0.10 & 0.10 & 0.10 & 0.10 \\
\hline
\end{tabular}

${ }^{1}$ DIM: $42 \pm 10 \mathrm{~d}$ postpartum, range: $26-58 \mathrm{~d}$ postpartum; ${ }^{2}$ DIM: $91 \pm 11 \mathrm{~d}$ postpartum, range: $73-109 \mathrm{~d}$ postpartum; significant differences were obtained between groups indicated with different letters; $* P<0.05 ; * * P<0.01 ; * * * P<0.001$.

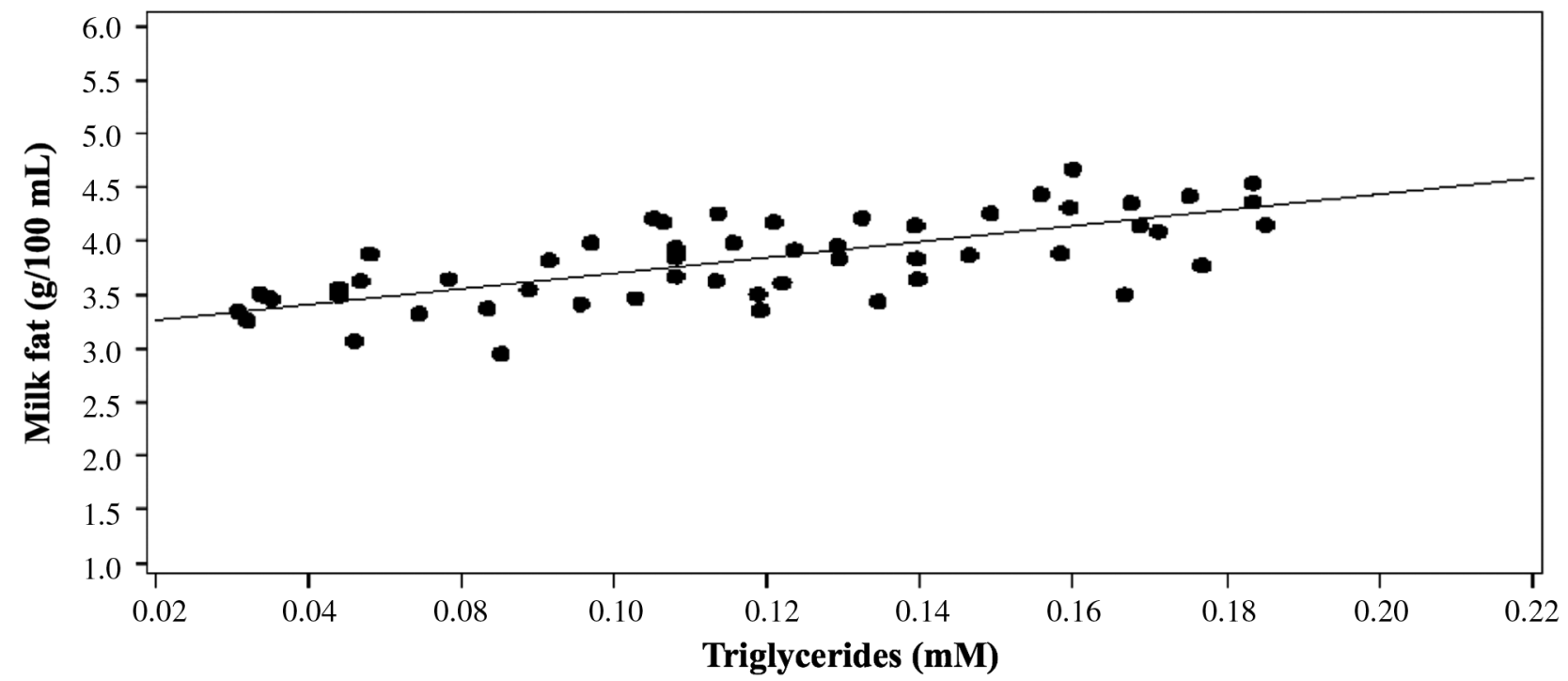

Figure 2. Relationship between milk fat and triglycerides ( $\mathrm{n}=63$ high-yield cows). Milk fat $(\bullet)$; predicted response (一). 


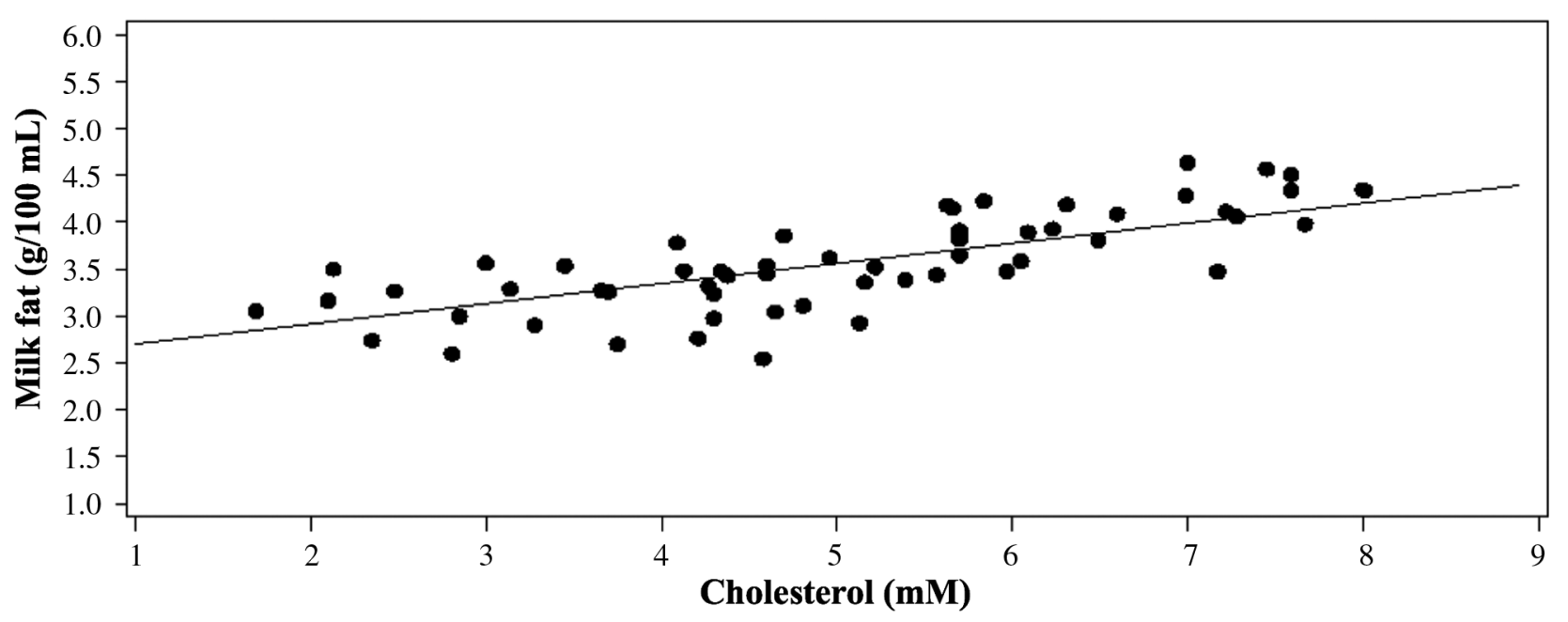

Figure 3. Relationship between milk fat and cholesterol ( $\mathrm{n}=63$ high-yield cows). Milk fat $(\bullet)$; predicted response (一).

mammary gland, increasing the fat content of milk, mainly with fatty acids of $\mathrm{C} 12$ to $\mathrm{C} 16$. This property has been exploited in vitro by using this protein as an emulsifying agent in food technology or as a fatty acid carrier in cell culture (Adjonu et al 2014).

On the other hand, a great part of the nitrogen contained in the RDP is converted by ruminal fermentation in ammonium ion $\left(\mathrm{NH}_{4}^{+}\right)$. This ion is absorbed by the ruminal wall and reaches the liver through the portal vein (Abdoun et al 2007), where the first contact of $\mathrm{NH}_{4}{ }^{+}$is with peri-portal hepatocytes, which have in their structure enzymes responsible for the synthesis of BUN (Noro and Wittwer 2012). This biochemical analyte was identified as a significant variable to explain the behaviour of milk protein, presenting a high coefficient $(\mathrm{r}=0.84 ; P<0.001)$ in high-yield cows (figure 4).

In the blood, BUN is a small neutral molecule, so it diffuses easily through cell membranes (Marini and van Amburgh 2003). Therefore, when its blood supply increases, it diffuses into the bovine mammary gland very easily, reflecting the existence of an isotonic balance between blood and milk, increasing the milk urea nitrogen (MUN).

Unlike energy deficiency, ion deficiency at NEB cannot be compensated by catabolism and utilisation of body reserves. Furthermore, the linear relationship between $\mathrm{Na}^{+}, \mathrm{K}^{+}$and $\mathrm{Cl}^{-}$and milk protein suggested that these three ions might be rate-limiting factors in the ability of the cows to express their genetic yield potential in early lactation. Consequently, ion depletion might obstruct the rate of increase in milk yield, and milk protein might be adjusted relative to ion availability. Hence, higher supplementation of $\mathrm{Na}^{+}, \mathrm{K}^{+}$and $\mathrm{Cl}^{-}$between weeks 1 and 8 in lactating dairy cows should increase retention of these ions and thus potentially improve feed intake and milk protein yield.

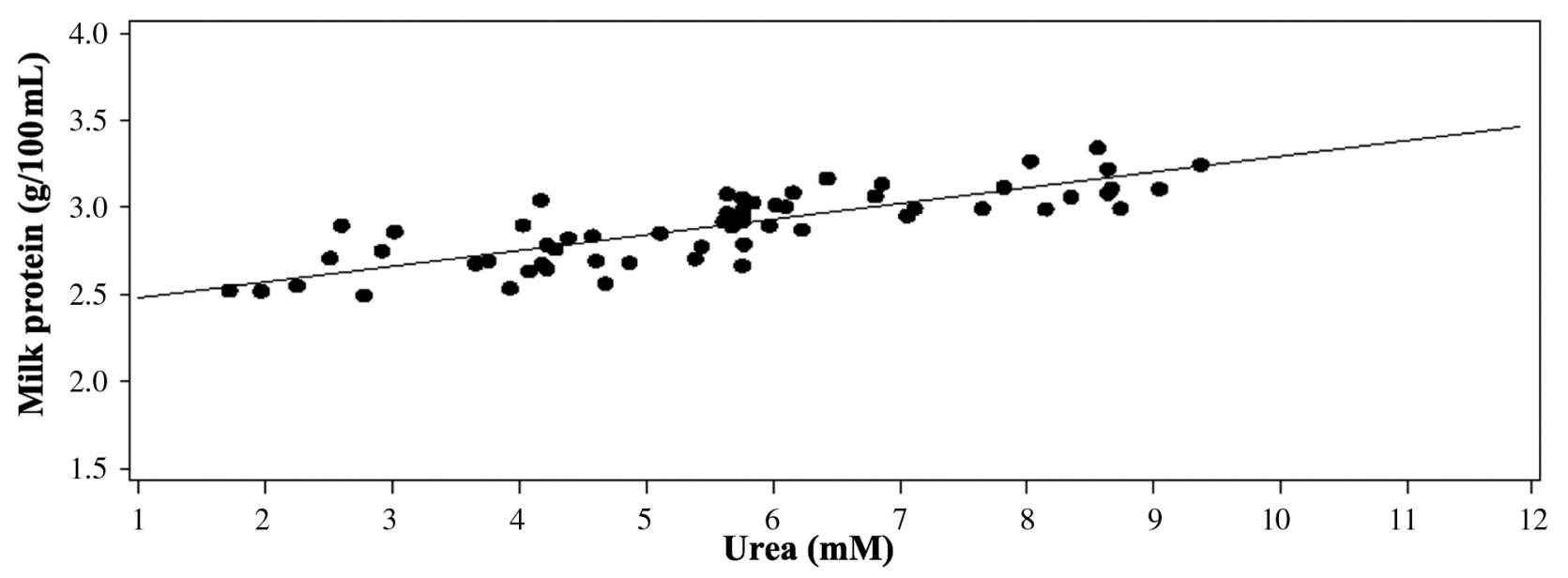

Figure 4. Relationship between milk protein and urea ( $n=63$ high-yield cows). Milk protein (•); predicted response (一). 
In conclusion, the milk fat level was positively correlated to COL, TAG, $\beta$-HBA and ALB at the high-yield cows. Milk protein level was positively correlated to urea, and negatively correlated to $\mathrm{Na}^{+}, \mathrm{K}^{+}$and $\mathrm{Cl}^{-}$at the high-yield cows. A virtually linear dependence has also been found between milk fat and TAG, between milk protein and urea, and between milk fat/protein ratio and COL, and TAG in low-yield cows. The results provide insight into the underlying physiological mechanisms to the lactation, and the identification of relationships between key analytes and components of milk, such as protein and fat content.

\section{ACKNOWLEDGEMENTS}

This project was supported by the National Council of Science and Technology-México (CONACyT-México) and the Thematic Network Academic Collaboration: Producción, Calidad, e Inocuidad de la Leche de Vaca, PRODEP.

\section{REFERENCES}

Abdoun K, Stumpff F, Martens H. 2007. Ammonia and urea transport across the rumen epithelium. Anim Health Res Rev 7, 43-59.

Adjonu R, Doran G, Torley P, Agboola S. 2014. Whey protein peptides as components of nanoemulsions: A review of emulsifying and biological functionalities. J Food Eng 122, 15-27.

Bauman DE, Mather IH, Wall RJ, Lock AL. 2006. Major advances associated with the biosynthesis of milk. J Dairy Sci 89, 1235-1243.

Bjerre-Harpoth V, Friggens NC, Thorup VM, Larsen T, Damgaard BM, et al. 2012. Metabolic and production profiles of dairy cows in response to decreased nutrient density to increase physiological imbalance at different stages of lactation. J Dairy Sci 95, 2362-2380.

Brscic M, Cozzi G, Lora I, Stefani AL, Contiero B, et al. 2015. Short communication: Reference limits for blood analytes in Holstein late-pregnant heifers and dry cows: Effects of parity, days relative to calving, and season. J Dairy Sci 98, 7886-7892.

Civeira F, Baila L, de Castro-Orós I, Mateo-Gallego R, Cenarro A. 2013. Novedades en el metabolismo lipídico. Nefrología 4, 23-29.

Duffield TF, Lissemore KD, McBride BW, Leslie KE. 2009. Impact of hyperketonemia in early lactation dairy cows on health and production. J Dairy Sci 92, 571-580.

Filipejová T, Kováčik J, Kirchnerová K, Foltýs V. 2011. Changes in milk composition as a result of metabolic disorders of dairy cows. Potravinárstvo 5, 10-16.

Folnožić I, Turk R, Đuričić D, Vince S, Pleadin J, et al. 2015. Influence of body condition on serum metabolic indicators of lipid mobilization and oxidative stress in dairy cows during the transition period. Reprod Domest Anim 50, 910-917.

García AB, Angeli N, Machado L, de Cardoso FC, González F. 2015ª Relationships between heat stress and metabolic and milk parameters in dairy cows in Southern Brazil. Trop Anim Health Prod 47, 889-894.

García CAC, Montiel RLA, Borderas TF, Girard V. 2015 . Relationship between $\beta$-hydroxybutyrate and fat/protein ratio of milk during early lactation in dairy cows. Arch Med Vet 47, 21-25.

García CAC, Prado FMG, Galicia LL, Borderas TF. 2017. Reference values for biochemical analytes in mexican dairy farms: interactions and adjustments between production groups. Arq Bras Med Vet Zoo 69, 445-456.

Harvatine KJ, Boisclair YR, Bauman DE. 2009. Recent advances in the regulation of milk fat synthesis. Animal 3, 40-54.

Herdt TH, Rumbeiha W, Braselton WE. 2000. The use of blood analyses to evaluate mineral status in livestock. Vet Clin North Am Food Anim Pract 16, 423-444.

Houillier P. 2014. Mechanisms and regulation of renal magnesium transport. Annu Rev Physiol 76, 411-430.
Houten SM, Wanders RJ. 2010. A general introduction to the biochemistry of mitochondrial fatty acid $\beta$-oxidation. $J$ Inherit Metab Dis 33, 469-477.

Kaneko JJ, Harvey WJ, Bruss LM. 2008. Appendix VIII Blood Analyte Reference Values in Large Animals. In: Kaneko JJ, Harvey WJ, Bruss LM, (ed). Clinical Biochemistry of Domestic Animals. $6^{\text {th }}$ ed. Academic Press, California, Estados Unidos, Pp 882-888.

Kim EJ, Huws SA, Lee MRF, Scollan ND. 2009. Dietary transformation of lipid in the rumen microbial ecosystem. Asian Aust J Anim Sci 22, 1341-1350.

Kraut JA, Madias NE. 2010. Metabolic acidosis: pathophysiology, diagnosis and management. Nat Rev Nephrol 6, 274-285.

Kume S, Sato T, Murai I, Kitagawa M, Nonaka K, et al. 2011. Relationships between urine $\mathrm{pH}$ and electrolyte status in cows fed forages. Anim Sci J 82, 456-460.

Le Maux S, Bouhallab S, Giblin L, Brodkorb A, Croguennec T. 2014. Bovine $\beta$-lactoglobulin/fatty acid complexes: binding, structural, and biological properties. Dairy Sci Technol 94, 409-426.

Liconsa. 2013. Scheme of prices and incentives for L of fluid milk, effective as of October 9, 2011. Social Supply Program. Acquisition of milk. Mexico City. Official Journal of the Federation 32, 216-230.

Manterola BH. 2011. Estrategias nutricionales y alimenticias para modificar los sólidos totales de la leche. Seminario Productividad en Sistemas Pastoriles Lecheros. Departamento de Producción Animal, Facultad de Ciencias Agronómicas, Universidad de Chile, Santiago, Chile, Pp 20.

Marini JC, van Amburgh ME. 2003. Nitrogen metabolism and recycling in Holstein heifers. J Anim Sci 81, 545-552.

McManaman JL, Neville MC. 2003. Mammary physiology and milk secretion. Adv Drug Deliv Rev 55, 629-641.

Nafikov RA, Beitz DC. 2007. Carbohydrate and lipid metabolism in farm animals. J Nutr 137, 702-705.

Noro M, Wittwer F. 2012. Relationships between liver ureagenesis and gluconeogenesis in ruminants fed with a high nitrogen diet. Vet México 43, 143-154.

NRC, National Research Council. 2001. Nutrient requirements of dairy cattle. $7^{\mathrm{a}}$ ed. National Academy Press, Washington, D. C., USA.

Oetzel GR. 2004. Monitoring and testing dairy herds for metabolic disease. Vet Clin North Am Food Anim Pract 20, 651-674.

Ospina PA, Nydam DV, Stokol T, Overton TR. 2010. Associations of elevated nonesterified fatty acids and $\beta$-hydroxybutyrate concentrations with early lactation reproductive performance and milk production in transition dairy cattle in the northeastern United States. J Dairy Sci $93,1596-1603$.

Payne JM. 1972. The future of presyntomatic diagnosis. Proc Roy Soc Med 65, 181-183.

Payne JM, Rowlands GJ, Manston R, Dew SM. 1973. A statistical appraisal of the results of metabolic profile tests on 75 dairy herds. Br Vet J 129, 370-381.

Peel MC, Finlayson BL, McMahon TA. 2007. Updated world map of the Köppen-Geiger climate classification. Hydrol Earth Syst Sci 11, 1633-1644.

Prodanović R, Sladojević Ž, Kirovski D, Vujanac I, Ivetić V, et al. 2012. Use of metabolic profiles and body condition scoring for the assessment of energy status of dairy cows. Biotech Anim Husbandry 28, 25-32.

Quiroz-Rocha GF, LeBlanc SJ, Duffield TF, Wood D, Leslie KE, et al. 2009. Reference limits for biochemical and hematological analytes of dairy cows one week before and one week after parturition. Can Vet J 50, 383-388.

Šamanc H, Kirovski D, Stojić V, Stojanović D, Vujanac I, et al. 2011. Application of the metabolic profile test in the prediction and diagnosis of fatty liver in Holstein cows. Acta Vet-Beograd 61, 543-553.

SAS, Statistical Analysis System. 2001. SAS version 8.2. SAS Institute Inc, Cary, NC, USA.

Soetan KO, Olaiya CO, Oyewole OE. 2010. The importance of mineral elements for humans, domestic animals and plants: A review. Afr J Food Sci 4, 200-222. 
Stojević Z, Piršljin J, Milinković-Tur S, Zdelar-Tuk M, Beer-Ljubić B. 2005. Activities of AST, ALT, and GGT in clinically healthy dairy cows during lactation and in the dry period. Vet Arhiv 75, 67-73.

van Saun RJ. 2006. Interpretation of pooled metabolic profiles for evaluating transition cow health status. XXIV World Buiatrics Congress, Nice, France, Pp 3-15. van Saun RJ. 2010. Indicators of dairy cow transition risks: metabolic profiling revisited. XXVI World Buiatrics Congress, Santiago, Chile, Pp 65-77.

Whitaker DA. 2000. Use and interpretation of metabolic profile. In: Andrews AH (ed). The health of dairy cattle. $1^{\text {st }} \mathrm{ed}$. Wiley Blackwell, Oxford, UK, Pp 89-107. 
